\title{
How Can the Celebrity Endorsement Effect Help Consumer Engagement? A Case of Promoting Tourism Products through Live Streaming
}

\author{
Luyi Qiu ${ }^{1,2}$, Xiaohua Chen ${ }^{3, *}$ and Timothy J. Lee ${ }^{4,5}$ \\ 1 Department of International Trade and Economics, Ningbo Polytechnic, Ningbo 315800, China; \\ 0000036@nbpt.edu.cn \\ 2 Business School, Universiti Kuala Lumpur (UniKL), Kuala Lumpur 50250, Malaysia \\ 3 Graduate School of Hotel \& Tourism, Kyung Hee University, Seoul 02447, Korea \\ 4 Faculty of Hospitality and Tourism Management, Macau University of Science and Technology (MUST), \\ Macao 999078, China; tjlee@must.edu.mo \\ 5 Griffith Institute for Tourism (GIFT), Griffith Business School, Griffith University, \\ Nathan, QLD 4111, Australia \\ * Correspondence: yidingxing@khu.ac.kr; Tel.: +82-2-961-0863
}

Citation: Qiu, L.; Chen, X.; Lee, T.J. How Can the Celebrity Endorsement Effect Help Consumer Engagement? A Case of Promoting Tourism Products through Live Streaming. Sustainability 2021, 13, 8655. https:// doi.org/10.3390/su13158655

Academic Editor: Osman M. Karatepe

Received: 23 June 2021

Accepted: 29 July 2021

Published: 3 August 2021

Publisher's Note: MDPI stays neutral with regard to jurisdictional claims in published maps and institutional affiliations.

\begin{abstract}
Although much research has been devoted to the study of the impact of celebrity endorsements on the effectiveness of advertising in the literature on consumer behavior, few scholars pay attention to applying this concept to explain consumer behavior in the tourism field. This research tested celebrities' expertise, trustworthiness, and attractiveness as the antecedents of consumer trust and engagement in the tourism and hospitality context. Specifically, through the analysis of 406 valid responses collected by online questionnaire, this study makes the following conclusions. First, it provides a new perspective on the influence of celebrity effects by focusing on the live-streaming behavior of CEOs on China's largest online travel agency (OTA) platform. Secondly, it confirms that the three dimensions of the celebrity effect (expertise, trustworthiness, and attractiveness) positively affect the three dimensions of consumer trust (ability, benevolence, and integrity). At the same time, consumer trust can also predict the three dimensions of consumer engagement (cognitive processing, affection, and activation). In addition, the three dimensions of consumer trust also play a positive mediating role between the relationship of celebrity effects and consumer engagement. That is, the celebrity effects have a positive and indirect influence on consumer engagement. Therefore, by suggesting that celebrity endorsements can create consumer trust and engagement in the OTA platform, this research expands the research framework of celebrity endorsement credibility theory.
\end{abstract}

Keywords: celebrity endorsement effects; consumer trust; benevolence; integrity; cognitive processing of engagement; activation of engagement

\section{Introduction}

Consumer trust is the core of the consumer relationship that directly promotes consumer engagement [1] and purchase behavior [2]. Consumer trust is gradually formed in constant interaction between consumers and the brand [3]. In the transaction process, compared to the sellers or producers, consumers have a relatively low degree of understanding of a brand, which leads to risk when they buy goods [4]. Thus, consumer trust reflects their expectations of the behavior of the trading platform [5]. Hence, the purpose of many companies' marketing strategies is to build customer trust or increase their engagement [1].

Celebrity endorsement has significant and practical effects in the advertising and marketing field [6]. Studies have demonstrated that celebrity effects enhance brandconsumer trust [7] or help in achieving a positive brand image [3], which have also been identified as playing essential roles in tourism marketing. This can also be explained by the trust transfer theory [8]. Generally, consumers initially lack trust in a trading platform 
or company. Still, if celebrities can represent the corporate image as endorsements, then consumers' trust in the celebrities will be transferred to related companies. For instance, when the CEO of a company endorses their own brand products, this also represents the personal issue of a "guarantee" to consumers that the products have undergone stringent quality inspections. This undoubtedly promotes the formation of consumer trust. However, given the critical role of celebrity effects in marketing, the related research on tourism is still insufficient. Moreover, the few tourism studies related to celebrity effects are limited to verifying the celebrity impact on the overall tourist attitudes $[9,10]$, or research that focuses on individuals' celebrity involvement [11,12], not the perspective of celebrity endorsement.

Moreover, consumer engagement has been identified as a meaningful emotional connection that can predict tourism product purchasing decisions [13]. However, the theoretical study of the celebrity effect in a tourism context is still at the initial stage [9]. Furthermore, there is little existing tourism research about the relationship between celebrity effects and consumer behavior [14]. Accordingly, the relationship between celebrity effects and consumer behaviors needs further research in different situations [15]. In summary, although unilateral studies on celebrity endorsement effects, consumer trust, and consumer engagement are gradually increasing in the field of tourism and hospitality, there are few that put the three together for empirical testing. Moreover, the mediating role of consumer trust between the celebrity effect and consumer engagement has also not been proven.

Therefore, this research attempts to incorporate the three concepts into the same theoretical framework, to build a conceptual model of the relationship between celebrity effect, consumer trust, and consumer engagement. Firstly, this study empirically tests whether the three dimensions of celebrity effect impact on the three dimensions of consumer trust (ability, benevolence, and integrity). Secondly, this paper confirms the influence of consumer trust on the three dimensions of consumer engagement (cognitive processing, affection, and activation). Thirdly, this research verifies the indirect influence of celebrity endorsement effects on consumer engagement. Ctrip, China's largest OTA platform, and its CEO were selected as the research context during this study process. On this basis, this research is expected to draw reliable theoretical research conclusions and then put forward more feasible marketing or management suggestions for tourism enterprises.

\section{Literature Review}

\subsection{Celebrity Endorsement Effects}

Celebrities enjoy public recognition, high popularity, and a particular reputation in society, and using this recognition to represent products or services in advertisements and publicize them is called celebrity endorsement [16]. The celebrity effect has become an effective marketing method, as celebrities' positive attributes can be transferred to brands [15]. Scholars have built relevant models, including the source credibility model [17] and the source attractiveness model [18]. Some scholars also put forward the Match-up hypothesis and stated that a celebrity's characteristics should positively correlate with brand attributes [19].

According to the source credibility model [20], the persuasive effect of endorsement information depends on the celebrity's expertise and trustworthiness perceived by the information receiver. Expertise refers to the degree of being considered capable of making correct assertions under relevant skills. Trustworthiness means the attributes of dignity, believability, and honesty of the spokespersons and as observed by audiences [21]. The source attractiveness model stated that messages from an appealing source could actively guide consumer behavior [18]. Attractiveness refers to a person's appearance, that is, a person who is considered beautiful, elegant, or classy $[17,20]$. Source attractiveness directly affects communication information effectiveness [18]. Moreover, familiarity, likeability, and similarity could also describe source attractiveness [22-24]. Later, many scholars gradually attributed source credibility and source attractiveness to the core celebrity endorsement theory $[7,25,26]$. 
It is an effective choice for a company to use the celebrity effect to carry out marketing activities to gain a competitive advantage [6,14]. Specific to tourism and hospitality, celebrities have become essential sources for shaping a destination's image [27] or enhancing a brand's equity [28]. More destination marketers and policymakers have realized the potential of celebrity effects and promoting celebrity-related tourism to ensure an attractive and competitive destination image [9,29]. Similarly, Wang et al. [10] examined that air transport service's celebrity credibility (consists of attractiveness, trustworthiness, and expertise) affected the purchase intention through a positive brand attitude and brand credibility. Kim et al. [28] showed that celebrity familiarity is also an essential factor for celebrity credibility, and familiarity significantly impacts brand equity in tourist destinations. There is also bound to be a matching problem between celebrities and tourism marketing.

Regarding the specific dimensions of celebrity endorsements, source credibility, attractiveness model, and celebrity-brand congruence [30] are three different research perspectives. Later, the source credibility and attractiveness model was unified into a threedimensional celebrity endorsement model [17], which scholars have often cited. In addition, some studies use familiarity instead of attractiveness [28]. In other words, the specific dimensions of celebrity endorsements can be different depending on the scholars' research contexts. In this study, the CEO is part of the company and has $100 \%$ consistency with the company, which is why the most basic three-dimensional structure was selected. Furthermore, as the representative and symbol of an organization, the CEO is widely recognized by the marketing and advertising practitioners for its importance in public communication and organizational image shaping [31]. Thus, CEOs have a significant influence on the persuasiveness of the product information [17]. However, specific to the object of this research-CEO celebrity, not all CEOs have the attributes of being celebrities. One paper [32] stated the belief that the concepts of fame and reputation can be used to understand the CEO celebrity. Fame means the degree to which the CEO is well-known and understood by the public. Fame is shaped by a particular time, place, or circumstance, and has relatively short-lived characteristics [32].

Cravens and Oliver [33] noted that reputation is mainly related to achievement and relatively stable features. Reputation is generated by relatively long-term media interaction, personal cultivation, or excellent performance. Moreover, according to fame and reputation, CEOs can be divided into four types: icons, hidden gems, silent killers, and scoundrels [32]. Hayward et al. [34] (p. 639) defined the CEO celebrity phenomenon as 'arises when journalists broadcast the attribution that a firm's positive performance has been caused by its CEO's actions.' Based on this, this research suggests that the CEO celebrity is the image of a CEO with the dual characteristics of fame and reputation in the public mind through newspapers, magazines, or other media. In addition, relative to celebrity endorsement effects, the study of CEO celebrities is still in its infancy [31,34]. Therefore, this study is from the perspective of celebrity endorsements to look at the positive impact that CEO celebrity can bring.

This article also attempts to explore the effect of celebrity endorsement effects in the OTA context. Based on the above literature analysis, this study deduced that there are three elements (expertise, trustworthiness, and attractiveness) suitable for a CEO's celebrity impact as an independent variable.

\subsection{Brand Trust and Celebrity Endorsement Effects}

Trust is defined as relying on the beliefs or intentions of the other party [35]. Wang et al. [10] noted that trust is based on past interactive experience and the belief that the other party's behavior can meet their expectations. Trust is essentially a simplification mechanism in social complexity, reducing the uncertainty of the transaction process [36], saving transaction costs, and promoting cooperation and interpersonal communication [37]. Liu et al. [38] also believed that trust means that one party believes that the other party can complete a specific transaction in an uncertain environment. Therefore, trust can reduce the cost (time and energy) consump- 
tion in the decision-making process [4]. Especially in a virtual environment, trust transfer is a way to establish initial trust [8]. The sociological theory states that trust can be transferred between individuals in the network [39]. This means that when individuals have a sense of trust in other customers or marketers on the shopping platform, they will have confidence in the shopping platform industry [8].

Since the rise of e-commerce, there have been many studies on consumer trust in shopping platforms context, but the definition of trust is not clear enough [2,40]. Trust is also a multi-dimensional variable, and the facets of integrity, benevolence, and ability have often been mentioned [37]. Integrity means that online travel platforms will sign contracts with consumers with good intentions, provide true and accurate transaction information, and transaction behaviors conform to general social transaction standards [41]. Benevolence refers to the online travel platform's contribution to consumers that exceed their interests. Considering the sense of responsibility and compassion in consumers, this can reduce transaction uncertainty and avoid opportunistic behavior [42]. Finally, ability is whether the online travel website is competent for the consumer's entrusted behavior [43].

Scholars believe that the higher the consumers' perceived celebrity credibility is, the higher their trust in brand performance will be [20]. Hussain et al. [44] indicated that celebrity credibility positively influences advertising reliability and consumer trust. These influences are moderated by consumers' ethnicity, not by age and gender. Consumer trust played an essential partial mediation role in the relationship between celebrity effects and purchase intention [38]. Dwivedi and Johnson [7] confirmed the celebrity effect's positive influence on consumer trust in the service context. Similarly, Wang et al. [10] proved that celebrity endorsement effects positively impact airline consumer trust. As a company representative, the CEO would be considered as one that better understands their products and brand characteristics and naturally the value of brand endorsement. Therefore, this research proposes the following hypotheses:

Hypotheses 1 (H1). The expertise of the CEO will positively affect the consumer trust-ability (H1a), benevolence $(\mathrm{H} 1 \mathrm{~b})$, and integrity $(\mathrm{H} 1 \mathrm{c})$ for the OTA platform;

Hypotheses 2 (H2). The trustworthiness of the CEO will positively affect the consumer trustability (H2a), benevolence (H2b), and integrity (H2c) for the OTA platform;

Hypotheses 3 (H3). The integrity of the CEO will positively affect the consumer trust-ability $(\mathrm{H} 3 a)$, benevolence $(\mathrm{H} 3 b)$, and integrity $(\mathrm{H} 3 \mathrm{c})$ for the OTA platform.

\subsection{Consumer Engagement and Consumer Trust}

Consumer engagement is defined as a kind of mind generated by customers interacting with the brand in a specific service relationship and creating an experience [45]. Customer engagement is a dynamic and cyclical process and has different performances in different situations [46,47]. Marketing scholars mainly define customer engagement from three perspectives. First, the behavioral perspective suggests that customer engagement is a non-transactional behavior of the customer to the brand. It is manifested in the spread of positive word-of-mouth, and so on. Second, the psychological perspective believes that customer engagement is the customer's emotional and cognitive responses toward a brand. Naumann et al. [48] believed that customer engagement is a psychological process that encourages new customers to generate loyalty and old customers to maintain loyalty. Finally, Mollen and Wilson [46] believed that customer engagement is their cognitive and emotional commitment with a brand.

From a comprehensive perspective, consumer engagement can be regarded as a multidimensional concept and includes multiple aspects of cognition, emotion, and behavior [49]. Vivek et al. [50] pointed out that customer engagement, including the three dimensions of conscious attention, enthused participation, and social connection. Mollen and Wilson [46] suggested that online consumer engagement includes three dimensions through quantitative research: active cognitive processing, instrumental value, and experience value. So et al. [13] confirmed that customer engagement had identification, enthusiasm, 
attention, absorption, and interaction. Hollebeek et al. [49] suggested that customer brand fit consists of three dimensions: cognitive processing, affection, and behavior. Moreover, the object of customer engagement can be products, brands, or activities [51]. Therefore, different types of customer engagement can be distinguished according to the objects of that engagement [52].

Scholars have pointed out that there is a positive relationship between consumer trust and engagement [53]. For instance, Wongkitrungrueng and Assarut [1] also found that customer trust in products and trust in sellers both greatly enriched customer engagement in social commerce's live streaming context. Finally, the research of Liu et al. [8] also indicates that in the social media brand community, consumer trust in other consumers or marketers positively impacts consumer engagement. Specifically, this research focuses on the OTA platform, and customer engagement includes three aspects of cognitive processing, affection, and activation. Thus, it can be theorized that consumer trust (ability, benevolence, and integrity) positively impacts consumer engagement:

Hypotheses 4 (H4). The ability of the OTA platform will positively affect consumer engagement (cognitive processing, affection, and activation);

Hypotheses 5 (H5). The benevolence of the OTA platform will positively affect consumer engagement (cognitive processing, affection, and activation);

Hypotheses 6 (H6). The integrity of the OTA platform will positively affect consumer engagement (cognitive processing, affection, and activation).

Based on the above literature review and study hypothesis, the conceptual framework of this research has been deduced as shown in Figure 1.

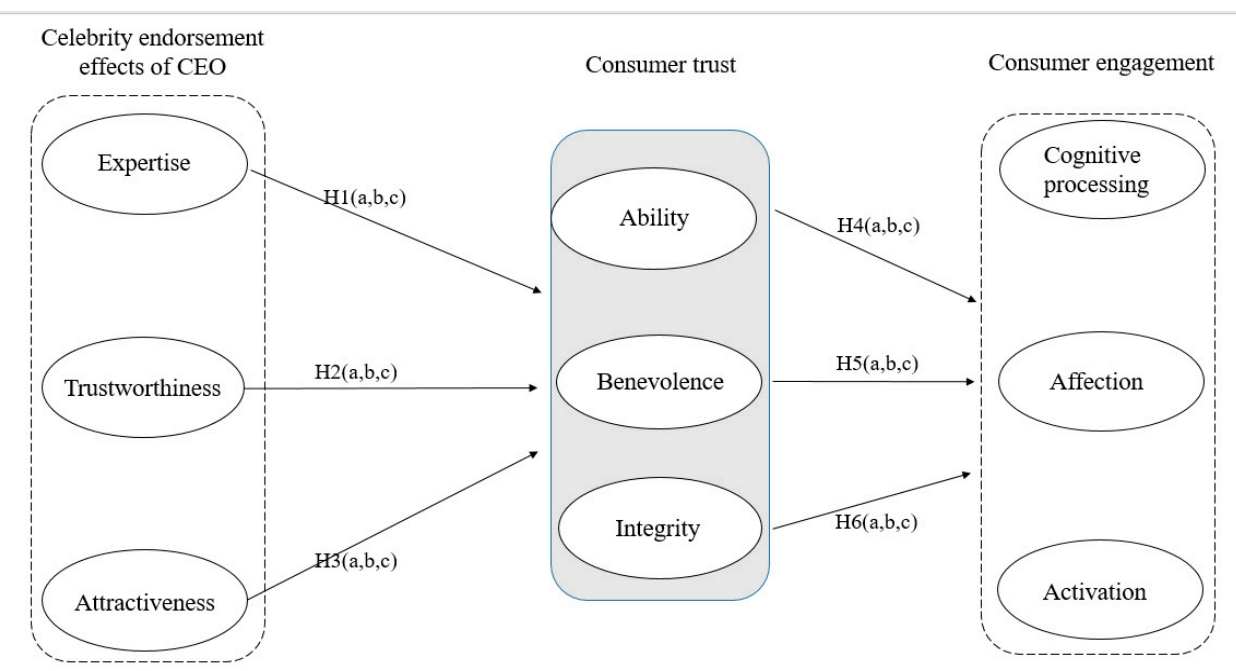

Figure 1. Conceptual framework.

\section{Methods}

\subsection{Survey Instrument}

This paper's measurement involves expertise, trustworthiness, attractiveness, consumer trust, consumer engagement, and several other variables. The study used a 5-point Likert scale, where 1 means strongly disagree and 5 means strongly agree, to examine these variables. As shown in Table 2, this paper adopted 15 items for expertise, trustworthiness, and attractiveness as per Ohanian's [17] structure. Then, consumer trust was analyzed with three dimensions (ability, benevolence, and integrity) as per Mayer and Davis [35]. Specifically, the ability dimension includes six items, for example, "This OTA site is very capable of performing its job". The benevolence dimension contains five items, and the integrity dimension contains six items (as shown in Table 3). The 10 measurement items for consumer engagement were from [49]. It includes three dimensions: cognitive processing, 
affection, and activation, with three, four, and three items, respectively. A representative item is "I spend a lot of time using this OTA site than other tourism sites".

\subsection{Data Collection}

This research aimed to survey adults who have used the 'CTRIP' OTA platform during the last 12 months. Before the questionnaire started, the respondent was shown a threeminute video material and given two-minute article reading material. Both the video and reading materials were about how the CEO of 'Ctrip', Mr. Liang, promotes tourism products through live streaming [54]. Specifically, the video material vividly explained how the CEO started to exert his influence to save the company during the COVID-19 pandemic. The video contains the CEO's motivation and unique understanding of why he started live streaming as well as shots of his incredible performance during these live broadcasts. Moreover, the reading materials showed the summary of a report from Ctrip.

Liang's first live streaming for the travel industry generated transactions valued at 10 million RMB (US\$1.65 million) of gross merchandise volume (GMV) within the first hour on 23 March 2020. As of the end of 2020, Ctrip has conducted 118 live streaming events and about 200 million consumers have booked travel products through the live broadcast room, and this has driven Ctrip's total pre-sale GMV to above 4 billion RMB (US \$62.6 million). Ctrip's live streaming could be seen in 274 cities in 28 countries during 2020. Furthermore, combining the characteristics of the destination, Liang has dressed up in 37 different costumes and ethnic outfits (see Figure 2) in the live broadcast room to promote tourism products $[54,55]$.

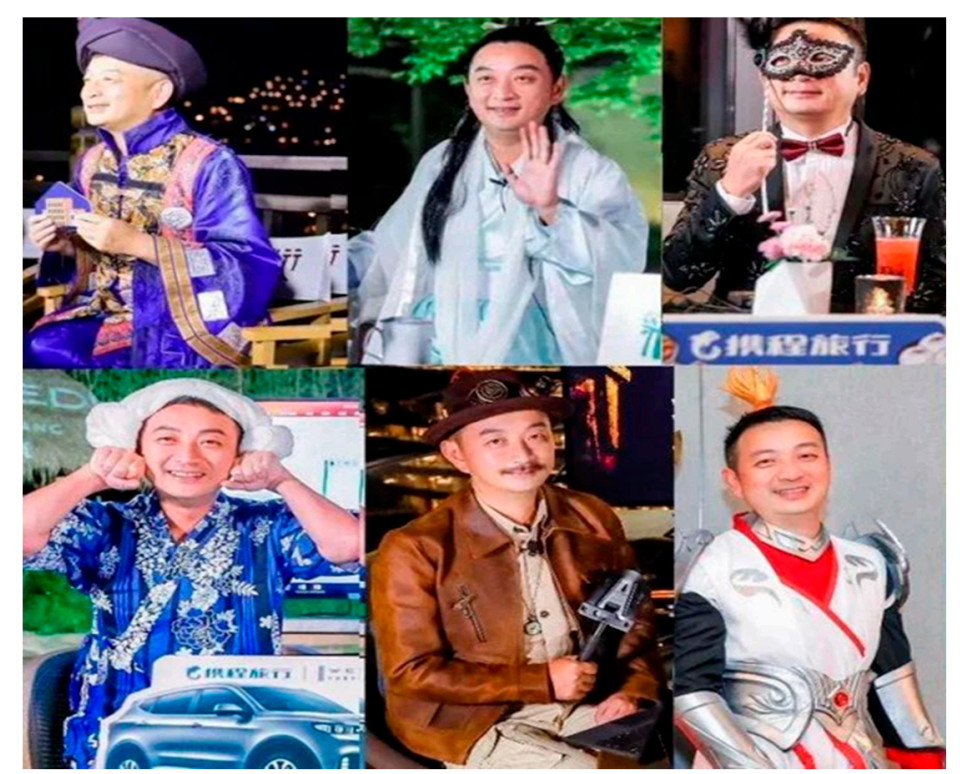

Figure 2. Examples of image viewed from the Ctrip platform. Source: The author (2021) adapted from $\mathrm{He} \& \mathrm{Li}$ [54].

This research first conducted a pilot test with 30 graduate students majoring in tourism management. To ensure a reliable and valid survey, some of the questionnaire items that were not clearly expressed were revised by being back-translated. Then, the main survey was conducted by an online survey via WenJuanXing (https://www.wjx.cn; accessed on 5 January 2021), a professional questionnaire survey website in China [56]. The participants were allowed to fill in the questionnaire after thoroughly reading the above materials about the CEO. Subsequently, from 5th to 10th January 2021, the current research achieved 455 questionnaire responses. After removing the outliers caused by dishonestly filling in responses (e.g., the same answer appears 15 times or more consecutively), 406 valid responses were finally determined. 


\subsection{Data Analysis}

The data analysis methods used in this study include descriptive analysis, exploratory factor analysis (EFA), confirmatory factor analysis (CFA), and structural equation modeling (SEM) analysis. The statistical software used includes SPSS 25.0 and AMOS 25.0. After the common method bias (CMB) of the data was tested, the two-step analysis method was recommended by Anderson and Gerbing [57]. First, the CFA was carried out based on a theoretical measurement model. Then, after a satisfactory construct model was obtained, the hypothetical relationships were tested. In addition, this study also tested the indirect effects of celebrity endorsement effects on consumer engagement based on the bootstrapping method recommended by Preacher and Hayes [58].

\section{Results}

\subsection{Overview of the Sample Population}

The sample structure is as follows (Table 1). In terms of gender, 216 are males, accounting for $53.2 \%$, and 190 are females, accounting for $46.8 \%$. In terms of age, those aged 31 to 40 account for $32.5 \%$ of responses, followed by those aged 21-30 (30.8\%). Additionally, participants with a bachelor's degree or above accounted for as much as $57.1 \%$ of the total sample. Moreover, $169(41.6 \%)$ respondents had a monthly income of $5001-10,000$ yuan (US\$763-1526). Thus, it can be seen that the users of OTA services were characterized by younger age and higher education.

Table 1. Socio-demographic characteristics of the main survey respondents $(n=406)$.

\begin{tabular}{|c|c|c|c|c|c|}
\hline Variable & Frequency & $(\%)$ & Variable & Frequency & $(\%)$ \\
\hline \multicolumn{3}{|c|}{ Age } & \multicolumn{3}{|c|}{ Monthly household income (RMB) } \\
\hline $18 \sim 20$ & 36 & 8.9 & 5000 or less & 94 & 23.2 \\
\hline $21 \sim 30$ & 125 & 30.8 & $5001-10,000$ & 169 & 41.6 \\
\hline $31 \sim 40$ & 132 & 32.5 & $10,001-15,000$ & 81 & 20.0 \\
\hline $41 \sim 50$ & 61 & 15.0 & $15,001-20,000$ & 45 & 11.1 \\
\hline $51 \sim 60$ & 32 & 7.9 & $20,001-30,000$ & 9 & 2.2 \\
\hline 61 or older & 20 & 4.9 & 30,001 or more & 8 & 2 \\
\hline \multicolumn{3}{|l|}{ Education background } & \multicolumn{3}{|l|}{ Gender } \\
\hline Finished middle school & 21 & 5.2 & Male & 216 & 53.2 \\
\hline High school graduate & 43 & 10.6 & Female & 190 & 46.8 \\
\hline \multirow{4}{*}{$\begin{array}{c}\text { Two-year college } \\
\text { Four-year university } \\
\text { Master's degree or } \\
\text { above }\end{array}$} & 110 & 27.1 & \multicolumn{3}{|c|}{ Marital status } \\
\hline & 214 & 52.7 & Single & 180 & 44.3 \\
\hline & 18 & 4.4 & Married & 219 & 53.9 \\
\hline & & & Other & 7 & 1.7 \\
\hline
\end{tabular}

Source: The author (2021).

\subsection{Validity and Reliability Test for Measures}

First, the data were tested for CMB. An EFA was performed on all potential variables using Harman's one-factor test method [59]. If the variance explanation rate of the first factor exceeds $50 \%$ before the rotation, this indicates that the data has a common method bias [60]. The results showed that the variance explanation rate of the first factor was $18.461 \%$, which indicates that the CMB of the data is acceptable. The Cronbach's $\alpha$ coefficients of all variables were between 0.830 (activation of engagement) and 0.930 (ability dimension), all higher than the 0.70 standard, indicating that the measurement scale has good internal consistency. At the same time, the composite reliability (CR) coefficients of all variables were between 0.831 and 0.931 (Table 2), which is greater than the 0.60 standards. Thus, the CR of the scale passed this test. In addition, the factor loads of all measurement items are more significant than 0.70 , which further proves that the scale of the research design can reliably measure the measured latent variables [61]. 
Table 2. Overview of constructs and items in the measurement model.

\begin{tabular}{|c|c|c|c|}
\hline Constructs and Items & $\begin{array}{c}\text { Factor } \\
\text { Loading }\end{array}$ & Mean & SD \\
\hline \multicolumn{4}{|c|}{ Expertise Dimension (Cronbach's $\alpha=0.915, C R=0.916, A V E=0.687$ ) } \\
\hline Expert & 0.833 & 4.195 & 0.561 \\
\hline Experienced & 0.830 & 4.227 & 0.542 \\
\hline Knowledgeable & 0.804 & 4.177 & 0.603 \\
\hline Qualified & 0.873 & 4.222 & 0.549 \\
\hline Skilled & 0.801 & 4.200 & 0.568 \\
\hline \multicolumn{4}{|c|}{ Trustworthiness Dimension (Cronbach's $\alpha=0.855, C R=0.856, A V E=0.542)$} \\
\hline Dependable & 0.703 & 4.106 & 0.618 \\
\hline Honest & 0.734 & 4.108 & 0.586 \\
\hline Reliable & 0.757 & 4.067 & 0.595 \\
\hline Sincere & 0.732 & 4.108 & 0.543 \\
\hline Trustworthy & 0.755 & 4.086 & 0.562 \\
\hline \multicolumn{4}{|c|}{ Attractiveness Dimension (Cronbach's $\alpha=0.889, C R=0.891, A V E=0.621$ ) } \\
\hline The CEO of this OTA is attractive & 0.754 & 4.200 & 0.602 \\
\hline Classy & 0.838 & 4.192 & 0.542 \\
\hline Handsome & 0.809 & 4.234 & 0.618 \\
\hline Elegant & 0.800 & 4.170 & 0.595 \\
\hline Sexy & 0.736 & 4.175 & 0.614 \\
\hline \multicolumn{4}{|c|}{ Ability Dimension (Cronbach's $\alpha=0.930, C R=0.931, A V E=0.693$ ) } \\
\hline This OTA site is very capable at performing its job. & 0.858 & 4.172 & 0.558 \\
\hline \multirow{5}{*}{$\begin{array}{l}\text { to do. } \\
\text { This OTA has much knowledge about the work that } \\
\text { needs to be done. } \\
\text { I feel very confident about the skills of this OTA. } \\
\text { This OTA has specialized capabilities that can increase } \\
\text { our performance. } \\
\text { This OTA is well qualified. }\end{array}$} & 0.799 & 4.172 & 0.571 \\
\hline & 0.820 & 4.209 & 0.547 \\
\hline & 0.848 & 4.163 & 0.561 \\
\hline & 0.832 & 4.143 & 0.583 \\
\hline & 0.836 & 4.138 & 0.517 \\
\hline \multicolumn{4}{|c|}{ Benevolence Dimension (Cronbach's $\alpha=0.860, C R=0.861, A V E=0.554)$} \\
\hline This OTA is very concerned about my welfare. & 0.730 & 4.128 & 0.684 \\
\hline \multirow{4}{*}{$\begin{array}{l}\text { My needs and desires are very important to this OTA. } \\
\text { This OTA would not knowingly do anything to hurt } \\
\text { me. } \\
\text { This OTA really looks out for what is important to me. } \\
\text { This OTA will go out of its way to help me. }\end{array}$} & 0.735 & 4.135 & 0.599 \\
\hline & 0.751 & 4.200 & 0.598 \\
\hline & 0.732 & 4.153 & 0.597 \\
\hline & 0.774 & 4.158 & 0.575 \\
\hline \multicolumn{4}{|c|}{ Integrity Dimension (Cronbach's $\alpha=0.897, C R=0.902, A V E=0.606$ ) } \\
\hline \multirow{2}{*}{$\begin{array}{l}\text { This OTA has a strong sense of justice. } \\
\text { I never have to wonder whether this OTA will stick to } \\
\text { its word. }\end{array}$} & 0.758 & 4.091 & 0.591 \\
\hline & 0.735 & 4.113 & 0.594 \\
\hline \multirow{4}{*}{$\begin{array}{l}\text { This OTA tries hard to be fair when dealing with } \\
\text { others. } \\
\text { This OTA's actions and behaviors are very consistent. } \\
\text { I like the values of this OTA. } \\
\text { Sound principles seem to guide this OTA's behavior. }\end{array}$} & 0.760 & 4.113 & 0.560 \\
\hline & 0.763 & 4.118 & 0.601 \\
\hline & 0.892 & 4.108 & 0.524 \\
\hline & 0.753 & 4.118 & 0.609 \\
\hline \multicolumn{4}{|c|}{ Cognitive processing of engagement (Cronbach's $\alpha=0.860, C R=0.862, A V E=0.677$ ) } \\
\hline \multirow{3}{*}{$\begin{array}{l}\text { Using this tourism site gets me to think about this OTA } \\
\text { site. } \\
\text { I think about this OTA site a lot when I'm using it. } \\
\text { Using this OTA site stimulates my interest to learn } \\
\text { more about this tourism site. }\end{array}$} & 0.786 & 4.175 & 0.597 \\
\hline & 0.859 & 4.155 & 0.578 \\
\hline & 0.821 & 4.145 & 0.593 \\
\hline \multicolumn{4}{|c|}{ Affection of engagement (Cronbach's $\alpha=0.888, C R=0.894, A V E=0.679$ ) } \\
\hline I feel very positive when I use this OTA site. & 0.895 & 4.197 & 0.588 \\
\hline Using this OTA site makes me happy. & 0.858 & 4.135 & 0.698 \\
\hline I feel good when I use this OTA site. & 0.775 & 4.165 & 0.584 \\
\hline I'm proud to use this OTA site. & 0.761 & 4.177 & 0.578 \\
\hline \multicolumn{4}{|c|}{ Activation of engagement (Cronbach's $\alpha=0.830, C R=0.831, A V E=0.621$ ) } \\
\hline \multirow{3}{*}{$\begin{array}{l}\text { I spend a lot of time using this OTA site, compared to } \\
\text { other tourism sites. } \\
\text { Whenever I'm using OTA sites, I usually use this site. } \\
\text { This OTA site is one of the brands I usually use when I } \\
\text { use tourism sites. }\end{array}$} & 0.756 & 4.089 & 0.555 \\
\hline & 0.788 & 4.084 & 0.611 \\
\hline & 0.819 & 4.071 & 0.590 \\
\hline
\end{tabular}


Validity was firstly tested by convergent validity. As shown in Table 3, the average variance extracted (AVE) of all variables is more significant than 0.50, indicating that all nine variables have convergent validity. Moreover, the AVE of all variables is more powerful than the square of the correlation coefficients of this variable and other variable, indicating that different variables can be distinguished with good discriminant validity [62]. In summary, the data in this article have good reliability and validity and are suitable for further data analysis and hypothesis testing.

Table 3. AVE and inter-construct correlations of the constructs in the CFA.

\begin{tabular}{cccccccccc}
\hline Constructs & $\mathbf{1}$ & $\mathbf{2}$ & $\mathbf{3}$ & $\mathbf{4}$ & $\mathbf{5}$ & $\mathbf{6}$ & $\mathbf{7}$ & $\mathbf{8}$ & $\mathbf{9}$ \\
\hline $\mathbf{1}$ & $\mathbf{0 . 6 8 7}$ & & & & & & & & \\
$\mathbf{2}$ & 0.401 & $\mathbf{0 . 5 4 2}$ & & & & & & \\
$\mathbf{3}$ & 0.520 & 0.368 & $\mathbf{0 . 6 2 1}$ & & & & & \\
$\mathbf{4}$ & 0.623 & 0.403 & 0.445 & $\mathbf{0 . 6 9 3}$ & & & & \\
$\mathbf{5}$ & 0.375 & 0.368 & 0.373 & 0.325 & $\mathbf{0 . 5 5 4}$ & & & \\
$\mathbf{6}$ & 0.521 & 0.408 & 0.486 & 0.465 & 0.356 & $\mathbf{0 . 6 0 6}$ & & \\
$\mathbf{7}$ & 0.428 & 0.346 & 0.419 & 0.437 & 0.454 & 0.417 & $\mathbf{0 . 6 7 7}$ & \\
$\mathbf{8}$ & 0.340 & 0.340 & 0.391 & 0.366 & 0.332 & 0.323 & 0.594 & $\mathbf{0 . 6 7 9}$ \\
$\mathbf{9}$ & 0.293 & 0.259 & 0.381 & 0.338 & 0.331 & 0.331 & 0.361 & 0.239 & $\mathbf{0 . 6 2 1}$ \\
\hline
\end{tabular}

Note: 1 = Expertise; 2 = Trustworthiness; 3 = Attractiveness; 4 = Ability; 5 = Benevolence; $6=$ Integrity; 7 = Cognitive processing of engagement; 8 = Affection of engagement; 9 = Activation of engagement; Diagonal values (bold) are AVE values. Off-diagonal values (plain) were squared inter-construct correlations of the constructs.

\subsection{Structure Model and Hypothesis Testing}

In this study, the fit indices $\left(\chi^{2}(783)=1608.981\right.$, CFI $=0.931$, TLI $=0.925$, RM$\mathrm{SEA}=0.051)$ suggested that the structural model fit well to the data [61]. Next, regarding the relationship between celebrity endorsement effects and consumer trust, as shown in Table 4, the analysis of SEM shows that expertise has significant positive effects on ability $(\beta=0.555, p<0.001)$, benevolence $(\beta=0.205, p=0.005)$, and integrity $(\beta=0.360, p<0.001)$, indicating that $\mathrm{H} 1 \mathrm{a}, \mathrm{H} 1 \mathrm{~b}$, and $\mathrm{H} 1 \mathrm{c}$ are accepted. Trustworthiness is significant in relation to ability $(\beta=0.193, p<0.001)$, benevolence $(\beta=0.314, p<0.001)$, and integrity $(\beta=0.235$, $p<0.001)$, so $\mathrm{H} 2 \mathrm{a}, \mathrm{H} 2 \mathrm{~b}$, and $\mathrm{H} 2 \mathrm{c}$ are supported. Similarly, attractiveness has a significant positive impact on ability $(\beta=0.159, p=0.006)$, benevolence $(\beta=0.301, p<0.001)$, and integrity $(\beta=0.305, p<0.001)$; thus, $\mathrm{H3a}, \mathrm{H} 3 \mathrm{~b}$, and $\mathrm{H} 3 \mathrm{c}$ are accepted. Then, the relationship of consumer trust (ability, benevolence, and integrity) and consumer engagement (cognitive processing, affection of engagement, and activation of engagement) was tested. Ability had a significant positive impact on the cognitive processing $(\beta=0.233, p<0.001)$, affection of engagement $(\beta=0.291, p<0.001)$, and activation of engagement $(\beta=0.251, p<0.001)$. Moreover, benevolence positively affected the cognitive processing $(\beta=0.527, p<0.001)$, affection of engagement $(\beta=0.483, p<0.001)$, and activation of engagement $(\beta=0.320$, $p<0.001)$.

Similarly, integrity positively affected the cognitive processing $(\beta=0.221, p<0.001)$, affection of engagement $(\beta=0.178, p=0.001)$, and activation of engagement $(\beta=0.226$, $p<0.001$ ). Therefore, H4, H5, and H6 have been verified. Furthermore, $\mathrm{R}^{2}$ for ability was 0.671, showing that the celebrity endorsement effects (expertise, trustworthiness, and attractiveness) of the CEO had $67.1 \%$ explanatory power in the ability dimension of consumer trust. Benevolence and integrity showed $51.6 \%$ and $63.0 \%$ explanatory power. Additionally, 0.718 represented that $71.8 \%$ of the cognitive processing of engagement was explained by consumer trust (ability, benevolence, and integrity). Consumer trust explained $67.3 \%$ of the affection of engagement's variance and $46.3 \%$ of the activation of engagement. Therefore, the celebrity endorsement effects have good explanatory power in relation to the outcome variables. The concrete results are shown in Table 4 and Figure 3. 
Table 4. Hypothesis testing results.

\begin{tabular}{|c|c|c|c|}
\hline Hypothesis & $\beta$ & $p$-Value & Result \\
\hline $\mathrm{H} 1 \mathrm{a}=$ Expertise $\rightarrow$ Ability & 0.555 & $<0.001$ & Supported \\
\hline $\begin{array}{l}\mathrm{H} 1 \mathrm{~b}=\text { Expertise } \rightarrow \\
\text { Benevolence }\end{array}$ & 0.204 & $=0.005$ & Supported \\
\hline $\mathrm{H} 1 \mathrm{c}=$ Expertise $\rightarrow$ Integrity & 0.360 & $<0.001$ & Supported \\
\hline $\begin{array}{l}\mathrm{H} 2 \mathrm{a}=\text { Trustworthiness } \rightarrow \\
\text { Ability }\end{array}$ & 0.193 & $<0.001$ & Supported \\
\hline $\begin{array}{l}\mathrm{H} 2 \mathrm{~b}=\text { Trustworthiness } \rightarrow \\
\text { Benevolence }\end{array}$ & 0.314 & $<0.001$ & Supported \\
\hline $\begin{array}{l}\mathrm{H} 2 \mathrm{c}=\text { Trustworthiness } \rightarrow \\
\text { Integrity }\end{array}$ & 0.235 & $<0.001$ & Supported \\
\hline $\begin{array}{l}\mathrm{H} 3 \mathrm{a}=\text { Attractiveness } \rightarrow \\
\text { Ability }\end{array}$ & 0.159 & $=0.006$ & Supported \\
\hline $\begin{array}{l}\mathrm{H} 3 \mathrm{~b}=\text { Attractiveness } \rightarrow \\
\text { Benevolence }\end{array}$ & 0.301 & $<0.001$ & Supported \\
\hline $\begin{array}{l}\mathrm{H} 3 \mathrm{c}=\text { Attractiveness } \rightarrow \\
\text { Integrity }\end{array}$ & 0.305 & $<0.001$ & Supported \\
\hline $\begin{array}{l}\mathrm{H} 4 \mathrm{a}=\text { Ability } \rightarrow \text { Cognitive } \\
\text { processing of engagement }\end{array}$ & 0.233 & $<0.001$ & Supported \\
\hline $\begin{array}{l}\mathrm{H} 4 \mathrm{~b}=\text { Ability } \rightarrow \text { Affection of } \\
\text { engagement }\end{array}$ & 0.291 & $<0.001$ & Supported \\
\hline $\begin{array}{l}\mathrm{H} 4 \mathrm{c}=\text { Ability } \rightarrow \text { Activation of } \\
\text { engagement }\end{array}$ & 0.251 & $<0.001$ & Supported \\
\hline $\begin{array}{l}\mathrm{H} 5 \mathrm{a}=\text { Benevolence } \rightarrow \\
\text { Cognitive processing of } \\
\text { engagement }\end{array}$ & 0.527 & $<0.001$ & Supported \\
\hline $\begin{array}{l}\mathrm{H} 5 \mathrm{~b}=\text { Benevolence } \rightarrow \\
\text { Affection of engagement }\end{array}$ & 0.483 & $<0.001$ & Supported \\
\hline $\begin{array}{l}\mathrm{H} 5 \mathrm{c}=\text { Benevolence } \rightarrow \\
\text { Activation of engagement }\end{array}$ & 0.320 & $<0.001$ & Supported \\
\hline $\begin{array}{l}\text { H6a }=\text { Integrity } \rightarrow \text { Cognitive } \\
\text { processing of engagement }\end{array}$ & 0.221 & $<0.001$ & Supported \\
\hline $\begin{array}{l}\text { H6b }=\text { Integrity } \rightarrow \text { Affection } \\
\text { of engagement }\end{array}$ & 0.178 & $=0.001$ & Supported \\
\hline $\begin{array}{l}\text { H6c = Integrity } \rightarrow \text { Activation } \\
\text { of engagement }\end{array}$ & 0.226 & $<0.001$ & Supported \\
\hline
\end{tabular}

Note: $\chi^{2}{ }_{(798)}=1945.826, \mathrm{CFI}=0.904, \mathrm{TLI}=0.896, \mathrm{RMSEA}=0.060 . \mathrm{R}^{2}$ for Ability $=0.671$; Benevolence $=0.516$; Integrity $=0.630 ;$ Cognitive processing of engagement $=0.718$; Affection of engagement $=0.673$; Activation of engagement $=0.463$. 
Celebrity endorsement effects of CEO
Consumer trust

Consumer engagement

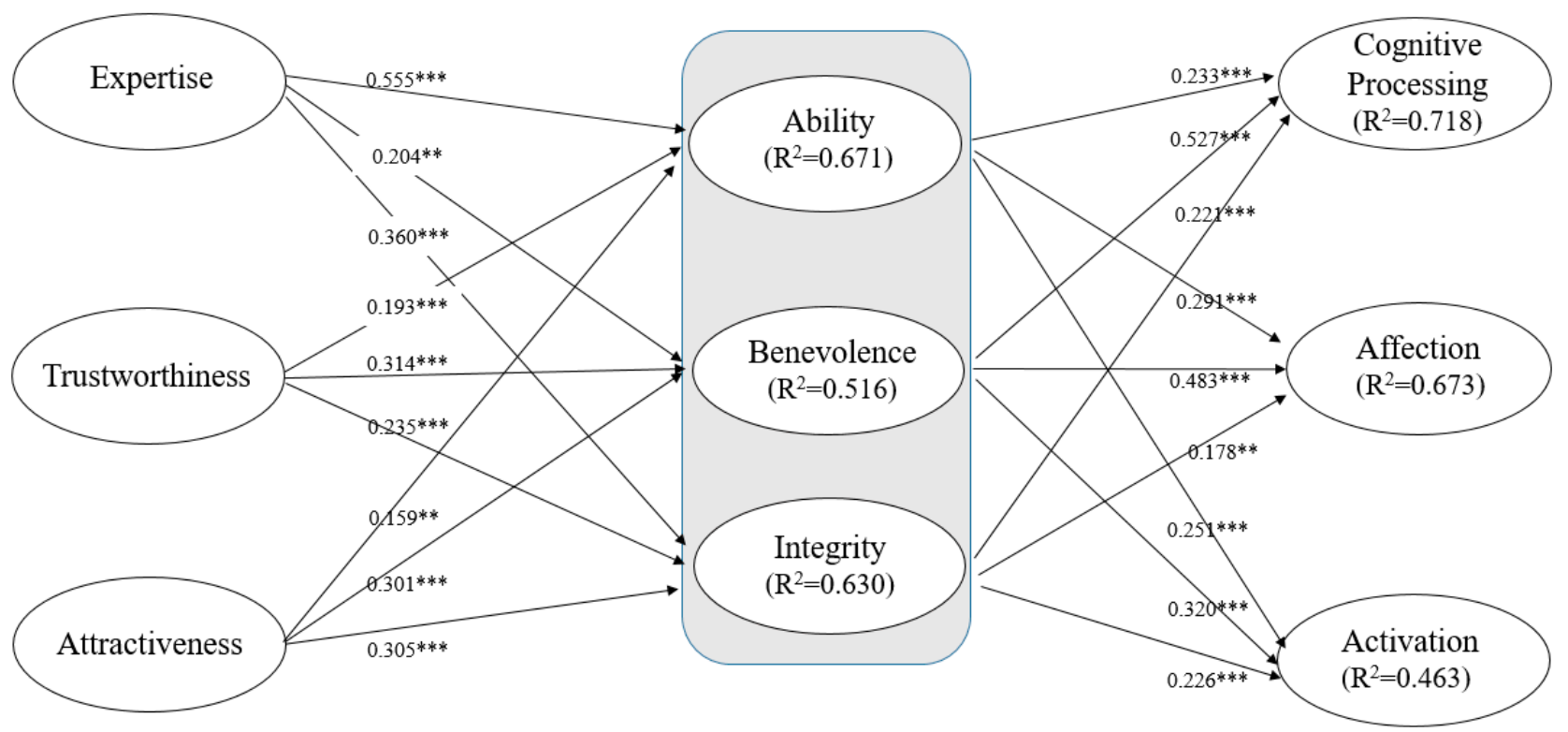

Figure 3. Final model with standardized path coefficient. ${ }^{* * *} p<0.001,{ }^{* *} p<0.01$.

Table 5. The results of the indirect effect analysis.

\begin{tabular}{|c|c|c|c|c|c|c|c|}
\hline & & Expertise & $\begin{array}{c}\text { Trust- } \\
\text { Worthiness }\end{array}$ & Attractiveness & Integrity & Benevolence & Ability \\
\hline \multirow{6}{*}{$\begin{array}{c}\text { Standardized } \\
\text { Total } \\
\text { Effects }\end{array}$} & Integrity & $0.360 * *$ & $0.235^{* *}$ & $0.305^{* *}$ & N.A. & N.A. & N.A. \\
\hline & Benevolence & 0.204 * & $0.314^{* *}$ & $0.301 * *$ & N.A. & N.A. & N.A. \\
\hline & Ability & $0.555^{* *}$ & $0.193^{* *}$ & $0.159 *$ & N.A. & N.A. & N.A. \\
\hline & Active & $0.286^{* *}$ & 0.202 ** & $0.205^{* *}$ & $0.226^{* *}$ & $0.320 * *$ & $0.251 * *$ \\
\hline & Affection & $0.324 * *$ & $0.250 * *$ & $0.246^{* *}$ & 0.178 * & $0.483 * *$ & 0.291 * \\
\hline & Cognitive & $0.317^{* *}$ & $0.263 * *$ & $0.263 * *$ & $0.221 *$ & $0.527 * *$ & $0.233 *$ \\
\hline \multirow{6}{*}{$\begin{array}{l}\text { Standardized } \\
\text { Direct } \\
\text { Effects }\end{array}$} & Integrity & $0.360 * *$ & $0.235^{* *}$ & $0.305^{* *}$ & N.A. & N.A. & N.A. \\
\hline & Benevolence & $0.204 *$ & $0.314 * *$ & $0.301 * *$ & N.A. & N.A. & N.A. \\
\hline & Ability & $0.555^{* *}$ & $0.193^{* *}$ & $0.159 *$ & N.A. & N.A. & N.A. \\
\hline & Active & N.A. & N.A. & N.A. & $0.226^{* *}$ & $0.320 * *$ & $0.251^{* *}$ \\
\hline & Affection & N.A. & N.A. & N.A. & $0.178 *$ & $0.483 * *$ & 0.291 * \\
\hline & Cognitive & N.A. & N.A. & N.A. & $0.221 *$ & $0.527^{* *}$ & $0.233 *$ \\
\hline \multirow{6}{*}{$\begin{array}{l}\text { Standardized } \\
\text { Indirect } \\
\text { Effects }\end{array}$} & Integrity & N.A. & N.A. & N.A. & N.A. & N.A. & N.A. \\
\hline & Benevolence & N.A. & N.A. & N.A. & N.A. & N.A. & N.A. \\
\hline & Ability & N.A. & N.A. & N.A. & N.A. & N.A. & N.A. \\
\hline & Active & $0.286^{* *}$ & $0.202^{* *}$ & $0.205^{* *}$ & N.A. & N.A. & N.A. \\
\hline & Affection & $0.324 * *$ & 0.250 ** & 0.246 ** & N.A. & N.A. & N.A. \\
\hline & Cognitive & $0.317^{* *}$ & $0.263 * *$ & $0.263 * *$ & N.A. & N.A. & N.A. \\
\hline
\end{tabular}

** $p<0.01 ; * p<0.05$.

The mediating effect of the three dimensions of consumer trust on the relationship between celebrity endorsement effects (expertise, trustworthiness, and attractiveness) and consumer engagement (cognitive processing, affection, and activation) was tested. This study used the bootstrap bias-corrected confidence interval method recommended by Preacher and Hayes [58]. The specific results are shown in Table 5. The results proved that the mediating of consumer trust is established, and the three-dimensional of the celebrity endorsement effects can indirectly impact this engagement through consumer trust. For example, expertise has positive influences on the engagement in the order of affection of engagement $(\beta=0.324, p=0.01)$, activation of engagement $(\beta=0.317, p<0.01)$, and cognitive processing $(\beta=0.286, p<0.01)$. 


\section{Discussion and Conclusions}

\subsection{Discussion}

This paper reports on the formation mechanism of customer engagement in OTA platforms based on the celebrity endorsement effects theory. The results showed that all hypotheses have been confirmed in this study. First, Hypotheses 1, 2, and 3 are accepted, indicating that the celebrity endorsement effects also exist in the CEO context. All the three dimensions of the celebrity effect (expertise, trustworthiness, and attractiveness) have a positive effect on the three dimensions of customer trust: namely, ability, benevolence, and integrity. This result showed that the CEO, as the manager of an enterprise, has an endorsement effect similar with a celebrity. Second, Hypotheses 4, 5, and 6 are supported. If customers have trust in the platform (ability, benevolence, and integrity), they will gradually become customers that engage with the brand or company. Thirdly, the test of mediating the effect of consumer trust showed that all three dimensions play a significant mediating role between a CEO's celebrity effects and customer engagement. In addition, the direct and indirect effect analysis showed (Figure 3) that the expertise dimension of the celebrity effect has the most significant influence on the affection dimension of the engagement, and the trustworthiness and attractiveness dimensions of the celebrity effect have a strong impact on the cognitive process dimension of the engagement.

\subsection{Theoretical Contributions}

The specific theoretical implications are as follows. Above all, this paper studied celebrity endorsement effects from the perspective of the CEO. Unlike previous studies that only focused on stars, movie stars [11], and religious celebrities [63], this research focused on the CEO's celebrity effects on travel and tourism platform giants in China. Moreover, this research's framework has broader applications and can be employed to elucidate the celebrity influences in other tourism settings. Just as Yang [64] suggested because the tourism industry contains various attributes, more research on celebrity effects in different contexts is needed. All these findings have contributed to the enrichment of the use of the celebrity effects model in the tourism research context. Since celebrity endorsement effects in the tourism context have just begun and are far behind industry practice $[10,65]$, it is believed that the research framework presented in this paper can be usefully utilized in future tourism studies.

Second, this study divided consumer trust into the three dimensions of ability, benevolence, and integrity. Moreover, according to previous studies, the celebrity endorsement effects were analyzed from three dimensions: expertise, trustworthiness, and attractiveness. The empirical analysis found that the three dimensions of celebrity effects have different influences on consumer trust. For example, expertise had a more significant influence on ability than trustworthiness or attractiveness did. Trustworthiness had the most significant impact on benevolence, and attractiveness had the most excellent effect on integrity. This proved not only the close correlation between celebrity endorsements and consumer trust, but also the multifunctional nature of celebrity endorsement effects. Thus, this study helps in the understanding of the antecedents of consumer trust and engagement in different contexts. Through a more comprehensive understanding of the influence of celebrity endorsement effects on consumer trust in various dimensions, this study has contributed to the expansion of the tourism and hospitality literature.

Third, and different from previous research by Wongkitrungrueng and Assarut [1], who regarded consumer engagement as a single dimension, this paper analyzed consumer engagement from the three dimensions of cognitive processing, affection, and activation. Consumer engagement has become an important variable affecting consumer-brand relationships [13]. Although the importance of consumer engagement has become increasingly prominent [66], existing research has still not conducted an in-depth exploration in this field. Many marketing scholars have failed to identify factors that affect consumer engagement in the online consumption context [1]. Therefore, this study analyzes the 
engagement from multiple dimensions, which should help the in-depth understanding of consumer-brand relationships.

Finally, this paper enriches the trust transfer theory. The trust transfer model stated that the celebrity endorsement process is essentially the transfer process of celebrity trust $[28,29]$. This theory recognized the crucial mediating role of brand image and brand trust, but it lacks related empirical research. Moreover, the internal mechanisms of the celebrity effect that affect tourists' attitudes and behaviors are still unclear. This study examined the role of celebrity effects on consumer engagement from an extended brand trust transfer perspective. Thus, this study enriches the trust transfer theory's empirical research application situation based on conducting a more comprehensive theoretical framework in the tourism context.

\subsection{Managerial Implications}

This paper puts forward some practical suggestions based on empirical research results from the following perspectives. First, this study pointed out that celebrity effects of CEOs significantly influence platforms' consumer trust, and finally lead to a more robust engagement. COVID-19 has caused a comprehensive negative impact on the tourism industry [67], but there are significant differences in the ability of different companies to deal with risks. In the Ctrip case, the CEO has given full play to his leadership. During the pandemic, the CEO personally participated in live streaming and promoted tourism products as an endorser to help in the recovery of the tourism industry. From the perspective of consumers or peers, Ctrip, as an online travel giant, has played an excellent incentive role in restoring confidence in the tourism industry, which has been hit hard by the pandemic. This provides a perfect example of how companies deal with crises. Moreover, nowadays, the rapid development of media offers various channels for brand communication. Thus, stakeholders can take a more active attitude towards long-term company development by multiple methods.

Second, this research focused on the CEO promoting tourism products through live streaming. The empirical results of this study showed that the multiple dimensions of the CEO's celebrity endorsement effects have a positive impact on trust and engagement. In particular, comparing trustworthiness and attractiveness, expertise exerts a more significant influence on ability. Moreover, compared with expertise and attractiveness, trustworthiness exerts a more substantial impact on benevolence. Thus, it can be seen that expertise and trustworthiness play an essential role in the CEO's endorsement effects, which is emphasized to the audience in CEO endorsements. Unlike other celebrities, such as movie stars, consumers pay more attention to the specific professional content that the CEO can provide. To sum up, to better transfer celebrity effects into consumer engagement, stakeholders should not only pay attention to the promotion methods, but also pay attention to the development of related professional content. For example, in future CEO endorsement activities, the OTA platform can provide more abundant tourism- or hotel-related products. It can also add more exciting activities or discounts to the live streaming room to exert celebrity effects better.

\subsection{Limitations and Further Research}

This study analyzed the influence of CEO's endorsement on consumer trust and engagement from the perspective of the celebrity effects. However, it has some limitations, and future research can be deepened from the following aspects. First, considering that respondents' characteristics are different (past travel experience, OTA platform use experience, age, and so on), the consumer's perception of the CEO's endorsement effect may also be different. Thus, further research can do more analysis on the moderating effects of these variables. Second, future research can also use other relevant social psychology theories to explore the influence mechanism of the celebrity effect on tourist behavior. For example, basing this comment on self-congruity theory, when consumers think that they have strong congruence with a celebrity, they will generate more positive attitudes and higher purchase 
intentions toward the product being endorsed [68,69]. Finally, this article's research context and sample selection are mainly focused on Ctrip, the largest OTA platform in China. However, the phenomenon of CEOs as endorsers of brand advertising also exists in other countries or other industries, and different cultural backgrounds, website involvement, and online experience may have different influences on attitudes. Thus, the current research results may not be suitable for other contexts. Therefore, future research in different countries should be conducted to expand regional or industrial diversity and improve the general application of research conclusions.

Author Contributions: Conceptualization, L.Q.; and X.C.; methodology, X.C.; validation, L.Q.; writing-original draft preparation, L.Q. and X.C. writing-review and editing, T.J.L.; supervision, T.J.L.; funding acquisition, L.Q. and X.C. All authors have read and agreed to the published version of the manuscript.

Funding: This paper was supported by the Zhejiang Province Education Science Planning Key Projects Fund (Grant number: 2021SB059). This paper was supported by the China Scholarship Council.

Institutional Review Board Statement: The study was conducted according to the guidelines of the Declaration of Helsinki and approved by the Institutional Review Board of the Ningbo Poly technic (30 April 2021).

Informed Consent Statement: Informed consent was obtained from all subjects involved in the study. Data Availability Statement: Data sharing is not applicable.

Conflicts of Interest: The authors declare no conflict of interest. The funders had no role in the design of the study; in the collection, analyses, or interpretation of data; in the writing of the manuscript, or in the decision to publish the results.

\section{References}

1. Wongkitrungrueng, A.; Assarut, N. The role of live streaming in building consumer trust and engagement with social commerce sellers. J. Bus. Res. 2020, 117, 543-556. [CrossRef]

2. Kim, Y.; Peterson, R.A. A Meta-analysis of Online Trust Relationships in E-commerce. J. Interact. Mark. 2017, 38, 44-54. [CrossRef]

3. Han, S.H.; Nguyen, B.; Lee, T. Consumer-based chain restaurant brand equity, brand reputation, and brand trust. Int. J. Hosp. Manag. 2015, 50, 84-93. [CrossRef]

4. Ryu, Y.; Kim, S.; Kim, S. Does Trust Matter? Analyzing the Impact of Trust on the Perceived Risk and Acceptance of Nuclear Power Energy. Sustainability 2018, 10, 758. [CrossRef]

5. Ebrahim, R. The Role of Trust in Understanding the Impact of Social Media Marketing on Brand Equity and Brand Loyalty. J. Relatsh. Mark. 2019, 19, 287-308. [CrossRef]

6. Knoll, J.; Matthes, J. The effectiveness of celebrity endorsements: A meta-analysis. J. Acad. Mark. Sci. 2016, 45, 55-75. [CrossRef]

7. Dwivedi, A.; Johnson, L.W. Trust-Commitment as a Mediator of the Celebrity Endorser-Brand Equity Relationship in a Service Context. Australas. Mark. J. 2013, 21, 36-42. [CrossRef]

8. Liu, L.; Lee, M.K.; Liu, R.; Chen, J. Trust transfer in social media brand communities: The role of consumer engagement. Int. J. Inf. Manag. 2018, 41, 1-13. [CrossRef]

9. Van der Veen, R.; Song, H. Impact of the Perceived Image of Celebrity Endorsers on Tourists' Intentions to Visit. J. Travel Res. 2013, 53, 211-224. [CrossRef]

10. Wang, S.W.; Kao, G.H.-Y.; Ngamsiriudom, W. Consumers' attitude of endorser credibility, brand and intention with respect to celebrity endorsement of the airline sector. J. Air Transp. Manag. 2017, 60, 10-17. [CrossRef]

11. Yen, C.-H.; Croy, W.G.; Croy, G. Film tourism: Celebrity involvement, celebrity worship and destination image. Curr. Issues Tour. 2013, 19, 1027-1044. [CrossRef]

12. Yen, C.-H.; Teng, H.-Y. Celebrity Involvement, Perceived Value, and Behavioral Intentions in Popular Media-Induced Tourism. J. Hosp. Tour. Res. 2013, 39, 225-244. [CrossRef]

13. So, K.K.F.; King, C.; Sparks, B.A.; Wang, Y. The Role of Customer Engagement in Building Consumer Loyalty to Tourism Brands. J. Travel Res. 2014, 55, 64-78. [CrossRef]

14. Roy, S.; Dryl, W.; Gil, L.D.A. Celebrity endorsements in destination marketing: A three country investigation. Tour. Manag. 2021, 83, 104213. [CrossRef]

15. Baniya, R. Components of Celebrity Endorsement Affecting Brand Loyalty of Nepali Customers. J. Bus. Manag. Res. 2017, 2, 52-65. [CrossRef]

16. Silvera, D.H.; Austad, B. Factors predicting the effectiveness of celebrity endorsement advertisements. Eur. J. Mark. 2004, 38, 1509-1526. [CrossRef] 
17. Ohanian, R. Construction and Validation of a Scale to Measure Celebrity Endorsers' Perceived Expertise, Trustworthiness, and Attractiveness. J. Advert. 1990, 19, 39-52. [CrossRef]

18. McGuire, W.J. Attitudes and Attitude Change. In Handbook of Social Psychology; Gardner, L., Aronson, E., Eds.; Random House: New York, NY, USA, 1985; Volume 2, pp. 233-346.

19. Misra, S.; Beatty, S.E. Celebrity spokesperson and brand congruence. J. Bus. Res. 1990, 21, 159-173. [CrossRef]

20. Amos, C.; Holmes, G.; Strutton, D. Exploring the relationship between celebrity endorser effects and advertising effectiveness. Int. J. Advert. 2008, 27, 209-234. [CrossRef]

21. Friedman, H.H.; Termini, S.; Washington, R. The Effectiveness of Advertisements Utilizing Four Types of Endorsers. J. Advert. 1976, 5, 22-24. [CrossRef]

22. Erdogan, B.Z. Celebrity Endorsement: A Literature Review Celebrity Endorsement: A Literature Review. J. Mark. Manag. 2010, 15, 291-314. [CrossRef]

23. Ha, N.M.; Lam, N.H. The Effects of Celebrity Endorsement on Customer's Attitude toward Brand and Purchase Intention. Int. J. Econ. Financ. 2016, 9, 64. [CrossRef]

24. Osei-Frimpong, K.; Donkor, G.; Owusu-Frimpong, N. The Impact of Celebrity Endorsement on Consumer Purchase Intention: An Emerging Market Perspective. J. Mark. Theory Pr. 2019, 27, 103-121. [CrossRef]

25. Dwivedi, A.; Johnson, L.W.; McDonald, R.E. Celebrity endorsement, self-brand connection and consumer-based brand equity. J. Prod. Brand Manag. 2015, 24, 449-461. [CrossRef]

26. Nyamakanga, N.F.; Ford, M.; Viljoen, K. Local and international celebrity endorsers' credibility and consumer purchase intentions. Acta Commer. 2019, 19, 9. [CrossRef]

27. Glover, P. Celebrity Endorsement in Tourism Advertising: Effects on Destination Image. J. Hosp. Tour. Manag. 2009, 16, 16-23. [CrossRef]

28. Kim, S.; Choe, J.Y.; Petrick, J.F. The effect of celebrity on brand awareness, perceived quality, brand image, brand loyalty, and destination attachment to a literary festival. J. Destin. Mark. Manag. 2018, 9, 320-329. [CrossRef]

29. Lee, Y.-K.; Kim, S.; Lee, C.-K.; Kim, S.-H. The Impact of a Mega Event on Visitors' Attitude Toward Hosting Destination: Using Trust Transfer Theory. J. Travel Tour. Mark. 2014, 31, 507-521. [CrossRef]

30. Kamins, M.A. An Investigation into the "Match-up" Hypothesis in Celebrity Advertising: When Beauty May Be Only Skin Deep. J. Advert. 1990, 19, 4-13. [CrossRef]

31. Ranft, A.L.; Zinko, R.; Ferris, G.R.; Buckley, M.R. Marketing the Image of Management: The Costs and Benefits of CEO Reputation. Organ. Dyn. 2006, 35, 279-290. [CrossRef]

32. Ketchen, D.J.; Adams, G.L.; Shook, C.L. Understanding and managing CEO celebrity. Bus. Horiz. 2008, 51, 529-534. [CrossRef]

33. Cravens, K.S.; Oliver, E.G. Employees: The key link to corporate reputation management. Bus. Horiz. 2006, 49, 293-302. [CrossRef]

34. Hayward, M.L.A.; Rindova, V.P.; Pollock, T.G. Believing one's own press: The causes and consequences of CEO celebrity. Strat. Manag. J. 2004, 25, 637-653. [CrossRef]

35. Mayer, R.C.; Davis, J.H. The effect of the performance appraisal system on trust for management: A field quasi-experiment. J. Appl. Psychol. 1999, 84, 123-136. [CrossRef]

36. Morgan, R.M.; Hunt, S.D. The Commitment-Trust Theory of Relationship Marketing. J. Mark. 1994, 58, 20-38. [CrossRef]

37. Wang, L.; Law, R.; Hung, K.; Guillet, B.D. Consumer trust in tourism and hospitality: A review of the literature. J. Hosp. Tour. Manag. 2014, 21, 1-9. [CrossRef]

38. Liu, M.T.; Brock, J.L.; Shi, G.C.; Chu, R.; Tseng, T. Perceived benefits, perceived risk, and trust. Asia Pac. J. Mark. Logist. 2013, 25, 225-248. [CrossRef]

39. Kim, M.; Kim, J. The Influence of Authenticity of Online Reviews on Trust Formation among Travelers. J. Travel Res. 2019, 59, 763-776. [CrossRef]

40. King, R.C.; Schilhavy, R.A.; Chowa, C.; Chin, W.W. Do Customers Identify with Our Website? The Effects of Website Identification on Repeat Purchase Intention. Int. J. Electron. Commer. 2016, 20, 319-354. [CrossRef]

41. Dickinger, A. The Trustworthiness of Online Channels for Experience- and Goal-Directed Search Tasks. J. Travel Res. 2010, 50, 378-391. [CrossRef]

42. Gefen, D. Reflections on the dimensions of trust and trustworthiness among online consumers. Database Adv. Inf. Syst. 2002, 33, 38-53. [CrossRef]

43. Carnevale, M.; Loureiro, Y.K.; Kabadayi, S. Customer Value Creation for Risky Products: The Role of Brand Trust and Trusting Beliefs. J. Creat. Value 2018, 4, 1-21. [CrossRef]

44. Hussain, S.; Melewar, T.; Priporas, C.-V.; Foroudi, P.; Dennis, C. Examining the effects of celebrity trust on advertising credibility, brand credibility and corporate credibility. J. Bus. Res. 2020, 109, 472-488. [CrossRef]

45. Brodie, R.; Ilic, A.; Juric, B.; Hollebeek, L. Consumer engagement in a virtual brand community: An exploratory analysis. J. Bus. Res. 2013, 66, 105-114. [CrossRef]

46. Mollen, A.; Wilson, H. Engagement, telepresence and interactivity in online consumer experience: Reconciling scholastic and managerial perspectives. J. Bus. Res. 2010, 63, 919-925. [CrossRef]

47. Vohra, A.; Bhardwaj, N. Customer engagement in an e-commerce brand community. J. Res. Interact. Mark. 2019, 13, 2-25. [CrossRef] 
48. Naumann, K.; Bowden, J.; Gabbott, M. Expanding customer engagement: The role of negative engagement, dual valences and contexts. Eur. J. Mark. 2020, 54, 1469-1499. [CrossRef]

49. Hollebeek, L.D.; Glynn, M.S.; Brodie, R. Consumer Brand Engagement in Social Media: Conceptualization, Scale Development and Validation. J. Interact. Mark. 2014, 28, 149-165. [CrossRef]

50. Vivek, S.D.; Beatty, S.E.; Dalela, V.; Morgan, R.M. A Generalized Multidimensional Scale for Measuring Customer Engagement. J. Mark. Theory Pr. 2014, 22, 401-420. [CrossRef]

51. Han, S.H.; Chen, C.-H.S.; Lee, T.J. The interaction between individual cultural values and the cognitive and social processes of global restaurant brand equity. Int. J. Hosp. Manag. 2021, 94, 102847. [CrossRef]

52. Dressler, M.; Paunovic, I. A Typology of Winery SME Brand Strategies with Implications for Sustainability Communication and Co-Creation. Sustainability 2021, 13, 805. [CrossRef]

53. Ding, S.; Lin, J.; Zhang, Z. The Influences of Consumer-to-Consumer Interaction on Dissatisfactory Consumers' Repetitive Purchases in Network Communities. Sustainability 2021, 13, 869. [CrossRef]

54. He, X.; Li, S.X. Their 2020, Liang Jianzhang, Boss Live-Streaming 2020. Available online: http:/ / www.kankanews.com/a/2020-1 2-31/0039622051.shtml (accessed on 2 January 2021).

55. Minnews. Liang Jianzhang is Good at Fighting, Ctrip is Good at Fighting. Ctrip is Listed for the Second Time. 2021. Available online: https: / / min.news/en/economy/efd74002ec06d52a20b7f62f1f693484.html (accessed on 14 July 2021).

56. Jian, Y.; Zhou, Z.; Zhou, N. Brand cultural symbolism, brand authenticity, and consumer well-being: The moderating role of cultural involvement. J. Prod. Brand Manag. 2019, 28, 529-539. [CrossRef]

57. Anderson, J.C.; Gerbing, D.W. Structural equation modeling in practice: A review and recommended two-step approach. Psychol. Bull. 1988, 103, 411-423. [CrossRef]

58. Preacher, K.J.; Hayes, A. Asymptotic and resampling strategies for assessing and comparing indirect effects in multiple mediator models. Behav. Res. Methods 2008, 40, 879-891. [CrossRef] [PubMed]

59. Fuller, C.; Simmering, M.J.; Atinc, G.; Atinc, Y.; Babin, B.J. Common methods variance detection in business research. J. Bus. Res. 2016, 69, 3192-3198. [CrossRef]

60. Podsakoff, P.M.; MacKenzie, S.B.; Lee, J.-Y.; Podsakoff, N.P. Common method biases in behavioral research: A critical review of the literature and recommended remedies. J. Appl. Psychol. 2003, 88, 879-903. [CrossRef] [PubMed]

61. Hair, J.F.; Black, W.C.; Babin, B.J.; Anderson, R.E. Multivariate Data Analysis: A Global Perspective; Pearson Education: London, UK, 2010.

62. Fornell, C.; Larcker, D.F. Evaluating Structural Equation Models with Unobservable Variables and Measurement Error. J. Mark. Res. 1981, 18, 39-50. [CrossRef]

63. Kim, B.; Chen, Y. Effects of religious celebrity on destination experience: The case of Pope Francis's visit to Solmoe Shrine. Int. J. Tour. Res. 2019, 22, 1-14. [CrossRef]

64. Yang, W. Star power: The evolution of celebrity endorsement research. Int. J. Contemp. Hosp. Manag. 2018, 30, 389-415. [CrossRef]

65. Gilal, F.G.; Paul, J.; Gilal, R.G. Celebrity endorsement and brand passion among air travelers: Theory and evidence. Int. J. Hosp. Manag. 2020, 85, 102347. [CrossRef]

66. Ferreira, M.; Zambaldi, F. The Mediating Role of Consumer Engagement with the Brand Community and Its Effect on Corporate Reputation. Int. J. Media Manag. 2019, 21, 45-64. [CrossRef]

67. Rahimizhian, S.; Irani, F. Contactless hospitality in a post-Covid-19 world. Int. Hosp. Rev. 2020. [CrossRef]

68. Belanche, D.; Casaló, L.V.; Flavián, M.; Ibáñez-Sánchez, S. Understanding influencer marketing: The role of congruence between influencers, products and consumers. J. Bus. Res. 2021, 132, 186-195. [CrossRef]

69. Song, S.; Kim, H.-Y. Celebrity endorsements for luxury brands: Followers vs. non-followers on social media. Int. J. Advert. 2020, 39, 802-823. [CrossRef] 